\title{
Evaluation of a standardised assay for the measurement of antibodies to double-stranded (native) DNA
}

\author{
P. DAVIS, M. BURRINGTON, A. R. MORGAN, AND A. SAETRE \\ From the Rheumatic Disease Unit, University of Alberta, Edmonton, Alberta, Canada
}

SUMMARY A standardised commercially available radioimmunoassay kit for the detection of antibodies to native DNA (N-DNA) has been evaluated in clinical practice. This test system is shown to be a reliably reproducible method of detecting these antibodies. In addition, evaluation of the purity of the radiolabelled test antigen in this assay has shown it to be almost entirely double stranded (native) DNA with virtually no contamination with single stranded (denatured) DNA, and with few areas of single stranded breaks or ends in the duplex molecule. The inclusion of known standards and precise characterisation of the DNA has partially overcome variability in results and provides for interlaboratory standardisation which is lacking in the techniques used at present.

It has previously been shown that antibodies to double-stranded (ds) native DNA have a high degree of specificity for systemic lupus erythematosus (SLE) (Pincus et al., 1969; Hughes, 1971). In addition, serial studies of these antibodies during the course of the disease have shown that in most patients a good degree of correlation exists between antibody levels and evidence of disease remission or relapse (Lightfoot et al., 1973; Davis et al., 1977a). Several problems with radioimmunoassays for the detection of DNA antibodies remain to be resolved. The purity of DNA used in each assay has to be clearly defined, as sera from patients with systemic lupus erythematosus and many other diseases also contain antibodies to other polynucleotides, especially single-stranded (ss) DNA. Singlestranded DNA present as an impurity in test-DNA will cause spuriously high levels of antibody binding to be recorded (Winfield and Davis, 1974). The validity of DNA assay results, therefore, can be interpreted only with the knowledge of the specific nature of the DNA.

A further problem in quantitation of antibody to native DNA is standardisation, not only between laboratories but also in the same laboratory from year to year. This problem is compounded by the number of different assay systems and different

Requests for reprints: Dr P. Davis, Department of Medicine, Room 9-112 Clinical Sciences Building, University of Alberta, Edmonton, Alberta, Canada

Received for publication 7 March 1977 forms of DNA which are used in the different laboratories for detecting antibodies to ds DNA.

The development of a standardised commercially available assay for quantitation of DNA antibodies, suitable for routine clinical application, would potentially be of value. We have had the opportunity to test one such commercially available assay provided by Amersham/Searle ${ }^{1}$ and have demonstrated (Davis et al., 1977b) that a good degree of correlation occurs between the presence of antibodies to double-stranded DNA as detected by this method, and antibodies to double-stranded DNA as detected by the Millipore filter assay with the ${ }^{3} \mathrm{H}-\mathrm{DNA}$ procedure now used routinely in our laboratory.

The aim of the present study was to evaluate the use of this standardised assay in routine clinical practice after careful assessment of the purity of the radiolabelled DNA.

\section{Methods}

The Amersham/Searle kit assay is based on the Farr ammonium sulphate precipitation technique. All essential chemicals and apparatus are provided to perform this technique on a microassay basis; 42 sera can be tested with each kit, which is supplied

${ }^{1}$ Available from Radiochemical Centre, Amersham, Bucks, UK or Amersham/Searle, 2636 S Clearbrook Drive, Arlington Heights, Illinois 60005, USA and 400 Iroquois Shore Road, Oakville, Ontario, Canada. 
with detailed background information and technical instructions.

Each kit contains four known SLE standard sera whose DNA binding activity is expressed in arbitrary units of DNA bound. The 125I iodinelabelled double-stranded DNA is extracted from HeLa cells with a final concentration of $1 \mu \mathrm{g}$ DNA/ $\mathrm{ml}$, specific activity $200 \mathrm{mCi} / \mu \mathrm{g} \quad\left(\mathrm{MW} \simeq 10^{7}\right)$. Analysis on a caesium chloride gradient shows a single peak of radioactive DNA and no radioactivity in the RNA fraction. Selective absorption chromotography on hydroxy apatite shows $<1 \%$ single stranded DNA (Holian et al.,1975; Holian, personal communication, 1976).

This degree of purity of radioactive antigen has been confirmed in our own laboratory. The DNA was not found to contain significant contamination with ss DNA by the following criteria.

\section{ETHIDIUM BROMIDE TECHNIQUE (Morgan and}

Pulleybank, 1974)

Ethidium intercalates into the DNA duplex with, at low ionic strengths, a binding constant of around $10^{7} \mathrm{M}^{-1}$ and with a 50-fold increase in the fluorescence of ethidium. The high binding constant and the intrinsic sensitivity of fluorescence allows DNA to be very sensitively assayed, $0 \cdot 1 \mu \mathrm{g}$ being quantitated to $\pm 1 \%$. In order to differentiate between native and denatured DNA, the much lower stability of the short intramolecular base-pairing that occurs in denatured DNA relative to the fully duplex native DNA is exploited. Heat denatured DNA can be made completely single-stranded by raising the $\mathrm{pH}$ to 11.8 , while under the same conditions native DNA remains intact. Thus at $\mathrm{pH} 8$, owing to the short intramolecular base-pairing of denatured DNA, it shows a fluorescence about $50 \%$ that of native DNA at $\mathrm{pH} 8$. However, at $\mathrm{pH} 11.8$ no fluorescence is observed for denatured DNA at all owing to destabilisation of intramolecular basepaired regions. The fluorescence of native DNA at $\mathrm{pH} 11.8$ is about $70 \%$ that of native DNA at $\mathrm{pH} 8$ owing to the higher ionic strength necessary for buffering the system. For an unknown sample of DNA containing both denatured and native DNA equal volumes containing approximately $0.1 \mu \mathrm{g}$ samples are added to the $\mathrm{pH} 8$ and $\mathrm{pH} 11.8$ ethidium assay mixtures. As a worked example, a mixture of DNAs might give a fluorescence reading in arbitrary units of 100 at pH 8 and of 40 at pH 11.8. The latter is due only to native DNA, and therefore of the 100 fluorescent units at $\mathrm{pH} 8, \frac{100}{70} \times 40=57$ units are due to native DNA and therefore $100-57$ $=43$ units are due to denatured DNA. Since the latter has half the specific fluorescence of native DNA, the actual ratio of native to denatured DNA음 on a nucleotide basis is $\frac{57}{2 \times 43}=1: 1 \cdot 51$.

\section{Experimental}

DNA at approximately $1 \mathrm{~A}_{260}(50 \mu \mathrm{g} / \mathrm{ml}), 2-20 \mu \mathrm{l}, \frac{\overline{\bar{c}}}{\bar{N}}$ is added to $2 \mathrm{ml}$ of $\mathrm{pH} 8$ or $\mathrm{pH} 11.8$ ethidium assay mixture, the former being $5 \mathrm{mM}$ tris $\mathrm{HCl} \mathrm{pH} 8$, $0.1 \mathrm{mM}$ EDTA, $0.5 \mu \mathrm{g} / \mathrm{ml}$ ethidium bromide; the latter is $20 \mathrm{mM}$ potassium phosphate $\mathrm{pH} 11 \cdot 8, \overrightarrow{0}$ $0.1 \mathrm{mM}$ EDTA, $0.5 \mu \mathrm{g} / \mathrm{ml}$ ethidium bromide. The solutions are then read for their fluorescence against岕 the appropriate blank ethidium assay mixture with excitation at $525 \mathrm{~nm}$ and emission at $600 \mathrm{~nm}$. In our experience, the Turner 430 spectrofluorometero is an excellent machine with good long-term stability ${ }^{\circ}$ An argon laser now in use can be used to give much y higher sensitivity but the expense would not make ito a generally useful instrument. Great care must be? taken to use scrupulously clean glassware. We $\vec{c}$ recycle cuvettes and test-tubes, rinsing with glass $\frac{\mathbb{D}}{0}$ distilled water. Marking pens should be avoidedচ as the ink gives a very intense interfering fluorescence $\frac{3}{\sigma}$ which, when the cuvettes or test-tubes are washed $\stackrel{\mathbb{C}}{ }$ can contaminate the solution in trace amounts. The fluorometer is thermostated at room temperatiqg as the assay is sensitive to temperature. By this method the ${ }^{125} \mathrm{I}$ HeLa cell DNA was found contain $15 \%$ single-stranded areas of the DNA motes cule. As this technique will detect duplex DNA with significant amounts of denatured regions, this్ represents a substantially pure DNA preparation? Analysis on hydroxyapatite columns confirms the manufacturer's finding of no significant contamina 3 tion with predominantly ss DNA.

OPERATIONAL CRITERIA

The specificity of the test antigen for $n$ DNA in practice can be confirmed by either testing seráknown to contain antibody to ss DNA alone or by. inhibition of $\mathbf{n}$ DNA binding by preincubation of tes? sera with excess quantities of other polynucleotides including ss DNA.

Rabbit antisera were raised to ss DNA by immunising with ss DNA inked to MBSA in? complete Freund's adjuvant. The specificity of this antibody was confirmed by demonstrating binding of antiserum to heat-denatured ${ }^{3} \mathbf{H}$ labelled DNAS but not to n DNA. Rabbit antisera bound $67 \%$ of $3 \mathrm{H}$ labelled ss DNA (normal rabbits bound $<10 \%$ ).

On agar immunodiffusion plates sera from three sensitised rabbits failed to show precipitation lines? against the Amersham/Searle ${ }^{125}$ I HeLa cell DNA but did show precipitation lines against the sames antigen after heat denaturation. In addition, $n \vec{\Phi}$ 
significant binding of the HeLa cell DNA was demonstrated when tested with rabbit antisera using both a Millipore or Farr radioimmunoassay. Ten sera from patients with high levels of binding to the HeLa cell DNA were preincubated with a 20 -fold excess of both unlabelled ss DNA and $n$ DNA. Significant inhibition of DNA binding of up to $95 \%$ was demonstrated using excess n DNA but no sera showed inhibition of more than $9 \%$ when preincubated with ss DNA.

The procedure is performed according to the detailed instructions, and a curve of counts $\left({ }^{125} \mathrm{I}\right.$ counts) is plotted against the anti-DNA antibody concentration in units per $\mathrm{ml}$ using the standards included. Anti-DNA antibody concentration in the same units per $\mathrm{ml}$ in the unknown serum can then be extracted from the standard curve as drawn. In most cases, where anti-DNA antibody activity is greater than the maximum standard serum provided, these antibody activities can be calculated by repeating the test using dilutions of the unknown serum.

Using this technique we have tested 78 sera from 54 patients with SLE fulfilling the ARA criteria (Cohen et al., 1971), 50 sera from patients with classical rheumatoid arthritis (RA) fulfilling the ARA criteria (Ropes et al., 1959), 33 sera from patients with progressive systemic sclerosis (PSS), and 57 sera from patients with definite ankylosing spondylitis (AS) fulfilling the New York criteria (Bennett and Burch, 1967). Fifty sera from normal subjects have been evaluated for the presence of DNA antibodies and used as controls.

\section{Results}

Results of DNA antibody concentration in the serum tested are expressed in the Table. Using this kit, levels of DNA binding greater than 50 units were

Table Number of sera with elevated DNA binding as detected by kit assay in patients with SLE, PSS, AS, and $R A$

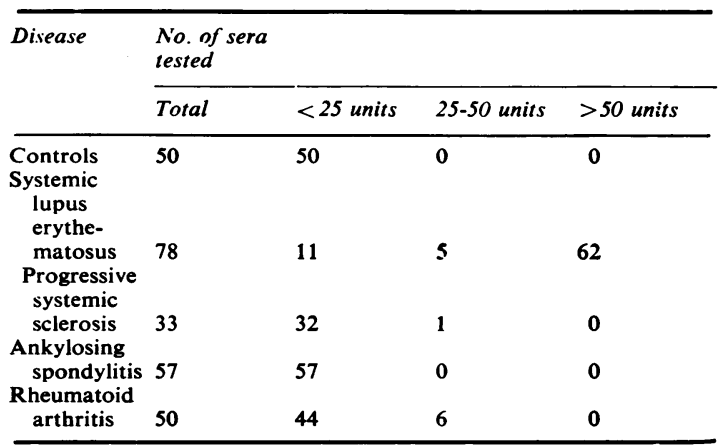

seen only in the sera from patients with SLE. No sera from the other disease groups tested had more than 50 units. Five sera from patients with SLE had 25-50 units of DNA binding, but levels in the same range were seen also in one serum from a patient with PSS and in six sera from patients with RA. All sera from patients with AS and the majority of sera from patients with RA and PSS bound less than 25 units of DNA.

Some patients with SLE whose disease was in remission also bound levels less than 25 units.

These results suggested that the upper limit of normal of 25 units of DNA bound per $\mathrm{ml}$, as expressed by the manufacturers, may be too low for the most effective differentiation between patients with SLE and other connective tissue diseases, particularly rheumatoid arthritis.

\section{Discussion}

Our results show that the Amersham/Searle assay kit is a convenient, reliable, and reproducible, method for detecting antibodies to double-stranded DNA. In particular, the kit has clinical value and does appear to differentiate between those sera containing significant amounts of n-DNA antibodies and those which do not, as has previously been reported (Holian et al., 1975). The few false positive results could be eliminated if the upper limit of normal were designated as $\mathbf{5 0}$ units per $\mathrm{ml}$.

The inclusion of known standards is an important factor as it allows for interlaboratory standardisation. In the past, however, most workers in this field have included known standards of their own when routinely testing for double-stranded DNA antibodies in their own laboratory using their own specific technique and DNA. This approach has led to day-to-day standardisation within one laboratory although it has not improved interlaboratory reference. While the inclusion of standards with the assay kit will overcome this to some extent it is perhaps unfortunate that another expression of results has had to be introduced (ie, units DNA bound $/ \mathrm{ml}$ ).

The main advantage of this assay system is the nature of the DNA used as test antigen. Recent reports have clearly shown that the differing antigens used in different centres do not necessarily react similarly in given test conditions. In particular, variations in molecular weight and contamination with ss DNA can significantly alter results (Aarden et al., 1975; Picazo and Tan, 1975).

This problem has previously been emphasised in other studies using differing assay systems and differing DNA (Winfield and Davis, 1974). Evaluation of the nature of the test antigen used is there- 
fore critical as impure antigen will lead to falsely high results which will reduce the sensitivity and specificity of the assay. Our assessment of the purity of the ${ }^{125}$ I HeLa cell DNA used in this kit, with the low levels of ss DNA, suggests a high degree of specificity of the antibody being measured. Although this DNA has a high MW $\left(10^{7}\right)$ relative to other DNAs, variations in MW due to age and batch with differing chain lengths will again be overcome by the inclusion of the known standards.

It is our opinion that this standardised assay and others like it will be of clinical value in measuring anti-DNA antibodies in the routine service laboratory and will improve the reliability with which DNA antibody results can be interpreted.

\section{References}

Aarden, L. A., Lakmaker, F., de Groot, E. R., Swaak, A. J. G., and Feltkamp, T. E. W. (1975). Detection of antibodies to DNA by radioimmunoassay and immunofluorescence. Scandinavian Journal of Rheumatology, Supplement, 11, 12-19.

Bennett, P. H., and Burch, T. A. (1967). New York symposium on population studies in the rheumatic diseases: new diagnostic criteria. Bulletin on Rheumatic Diseases, 17, 453-458.

Cohen, A. S., Reynolds, W. E., Franklin, E. C., Kulka, J. P., Ropes, M. W., Shulman, L. E., and Wallace, S. L. (1971). Preliminary criteria for the classification of systemic lupus erythematosus. Bulletin on Rheumatic Diseases, 21, 643-648.

Davis, P., Percy, J. S., and Russell, A. S. (1977a). Correlation between levels of DNA antibodies and clinical disease activity in SLE: retrospective evalua- tion. Annals of Rheumatic Diseases, 36, 157-159.

Davis, P., Percy, J. S., and Russell, A. S. (1977b). Ā comparative study of techniques for the detection of: antibodies to native desoxyribonucleic acid (N-DNA) American Journal of Clinical Pathology, 67, 374-378.

Holian, J., Griffiths, I. D., Glass, D. N., Maini, R. N.Cे and Scott, J. T. (1975). Human anti-DNA antibody reference standards for diagnosis and management of systemic lupus erythematosus. Annals of Rheumatio Diseases, 34, 438-443.

Hughes, G. R. V. (1971). Significance of anti-DNA antibodies in systemic lupus erythematosus. Lancet, 2 , 861-863.

Lightfoot, R. W., Redecha, P. B., and Levesanos, N. (1973). Longitudinal studies of anti-DNA antibodys levels in SLE. Scandinavian Journal of Rheumatology Supplement, 11, 52-58.

Morgan, A. R., and Pulleyblank, D. E. (1974). Nativẹ and denatured DNA, crosslinked and palindromic DNA and circulare covalently-closed DNA analysed by a sensitive fluorometric procedure. Biochemica? and Biophysical Research Communications, 61, 396-493-

Picazo, J. J., and Tan, E. M. (1975). Specificities of antibodies to native DNA. Scandinavian Journal of Rheumatology, Supplement, 11, 35-41.

Pincus, T., Schur, P. H., Rose, J. A., Decker, J. L., anc户ㄹ Talal, N. (1969). Measurement of serum DNA. binding activity in systemic lupus erythematosus. New England Journal of Medicine, 281, 701-705.

Ropes, M. W., Bennett, G. A., Cobb, S., Jacox, R., 迎 Jessar, R. A. (1959). 1958 revision of Diagnostide criteria for rheumatoid arthritis. Bulletin on Rheumatics Diseases, 9, 175-176.

Winfield, J. B., and Davies, J. S. (1974). Anti-DNA? antibody in procainamide-induced lupus erythemato? sus: determinations using DNA fractionated by methylated albumin-kieselguhr chromatography $\overrightarrow{\vec{O}}$ Arthritis and Rheumatism, 17, 97-110. 